\title{
PEMANFAATAN ENZIM RENNET dan Lactobacillus plantarum YN 1.3 TERHADAP pH, CURD dan TOTAL PADATAN KEJU
}

\author{
Stevani Budiman, R. Hadju*, S. E. Siswosubroto, G. D. G. Rembet \\ Fakultas Peternakan Universitas Sam Ratulangi Manado 95115
}

\begin{abstract}
ABSTRAK
Tujuan penelitian ini untuk mengetahui pemanfaatan enzim rennet dan Lactobacillus plantarum YN 1.3 terhadap $\mathrm{pH}$, curd dan total padatan keju. Rancangan penelitian yang digunakan pada penelitian ini adalah Rancangan Acak Lengkap (RAL) dengan perlakuan enzim rennet dan Lactobacillus plantarum YN 1.3 masingmasing perlakuan diulang sebanyak empat kali. Data yang diperoleh dianalisis menggunakan annova, kemudian dilanjutkan dengan uji Beda Nyata Jujur , dengan tools SPSS versi 20 untuk uji Tukey HSD. Hasil penelitian ini menunjukkan bahwa pemanfaatan enzim rennet dan Lactobacillus plantarum YN 1.3 memberikan pengaruh berbeda tidak nyata $(\mathrm{P}>0,05)$ terhadap $\mathrm{pH}$ dan memberikan pengaruh berbeda sangat nyata $(\mathrm{P}<0,01)$ terhadap curd dan total padatan keju. Berdasarkan hasil pembahasan dan analisis data dapat disimpulkan bahwa keju dengan pemanfaatan enzim rennet $2 \%$ dan Lactobacillus plantarum YN $1.3 \quad 8 \%$ menghasilkan $\mathrm{pH}$, curd dan total padatan keju terbaik.
\end{abstract}

Kata kunci: Keju, enzim rennet dan Lactobacillus plantarum YN 1.3

\section{ABSTRACT}

UTILIZATION of RENNET ENZYME and Lactobacillus plantarum YN 1.3 ON pH, CHEESE SOLIDS TOTAL and CURD. The aims of this

*Korespondensi (corresponding Author) Email: rahma.hadju@yahoo.com research was to know the rennet enzyme levels and utilization of Lactobacillus plantarum $Y N 1.3$ on Cheese $\mathrm{pH}$, solids total and curd. This research designed by a Completely Randomized Design, the treatments were the rennet enzyme levels and Lactobacillus plantarum YN 1.3. Each treatments has four times replications. The data obtained were analyzed using SPSS ver 20 tools and significant effects was test by Tukey HSD. The results of this research showed no significant difference $(p>0.05)$ on cheese $\mathrm{pH}$. Cheese solids total and curd has highly significant difference effects ( $p$ $<0,01)$. Based on the discussion and data analysis, can be concluded that the utilization of the rennet enzyme level $2 \%$ and Lactobacillus plantarum YN $1.38 \%$ produced good performs of $\mathrm{pH}$, total cheese solids and curd.

Key words: cheese, rennet enzyme and Lactobacillus plantarum YN 1.3

\section{PENDAHULUAN}

Susu sebagai produk utama dalam usaha peternakan sapi perah sangat potensial dalam mengatasi permasahalan gizi di Indonesia, hal ini di sebabkan karena susu merupakan makanan yang hampir sempurna yang mempunyai nilai gizi tinggi dengan kandungan nutrisinya yang lengkap dan cukup untuk memenuhi kebutuhan hidup manusia. Karena susunannya yang 
sangat sempurna maka susu merupakan media yang baik bagi pertumbuhan mikroorganisme, sehingga susu merupakan salah satu produk peternakan yang mudah rusak. Untuk itu di perlukan teknologi penanganan dan pengolahan dalam mempertahankan mutu gizinya. Salah satu alternative adalah dengan mengolah menjadi produk olahan susu dengan bentuk dan rasa baru yaitu produk keju.

Keju adalah salah satu hasil olahan susu yang di buat dengan cara memisahkan curd dengan whey. Penyusun utama keju adalah kasein, dan selebihnya terdiri atas protein whey, lemak, laktosa, vitamin, mineral.

Bakteri asam laktat akan mempengaruhi kecepatan perubahan laktosa menjadi asam laktat, selain itu juga akan mempengaruhi kecepatan penurunan $\mathrm{pH}$ dan konsentrasi asam yang dihasilkan pada keju. Tinggi rendahnya kadar asam laktat, mempengaruhi keju baik secara kimiawi maupun biologis. Bakteri asam laktat yang banyak digunakan dalam pembuatan keju seperti Lactococcus lactis, Streptococcus thermophilus, Lactobacillus casei, Lactobacillus acidophilus dan Lactobacillus plantarum

Kualitas dari keju juga ditentukan dengan penambahan enzim rennet. Enzim rennet merupakan salah satu bahan penggumpal kasein yang dibutuhkan dalam pembuatan keju. Bahan ini dapat diperoleh dalam bentuk ekstrak rennet bubuk atau tepung, yang dapat dibuat secara sederhana dari bahan abomasum (lambung ke 4) anak kambing yang masih menyusui atau ternak ruminansia lainnya. Enzim rennet sering juga disebut rennin. Merupakan zat yang digunakan untuk menggumpalkan susu pada proses awal pembuatan keju. Penambahan enzim ataupun asam dalam pembuatan keju bertujuan untuk menurunkan $\mathrm{pH}$ hingga 4,5-5,4 dimana $\mathrm{pH}$ tersebut merupakan titik isoelektrik kasein susu.

Berdasarkan uraian di atas telah dilakukan penelitian tentang pemanfaatan enzim rennet dan Lactobacillus plantarum YN 1.3 terhadap $\mathrm{pH}$, curd dan total padatan keju.

\section{MATERI DAN METODE PENELITIAN}

Penelitian ini telah dilaksanakan pada bulan November 2016 sampai Januari 2017 di Laboratorium Teknologi Hasil Ternak, Fakultas Peternakan, Universitas Sam Ratulangi Manado.

Bahan-bahan yang digunakan dalam penelitian yaitu: susu segar 20 litter yang diambil dari Balai Pengembangan Bibit dan Pakan Ternak di Desa Tampusu, enzim rennet, susu skim, asam asetat $10 \%$, garam, MRS Broth, auqudest, kapas, karet, alcohol $70 \%$, tisu, spritus, alumunium foil 
dan bakteri asam laktat (Lactobacillus plantarum YN 1.3

Alat-alat yang digunakan dalam penelitian ini yaitu: autoclave, timbangan digital, incubator, pisau, telenan, lemari pendingin, erlenmeyer, streer, centrifuge, tabung reaksi, kompor, gelas piala, thermometer.

Rancangan penelitian yang digunakan pada penelitian ini adalah Rancangan Acak Lengkap (RAL) dengan perlakuan enzim rennet dan Lactobacillus plantarum $\quad Y N \quad 1.3 \quad$ masing-masing perlakuan diulang sebanyak empat kali. Data yang diperoleh dianalisis menggunakan anova, kemudian dilanjutkan dengan uji beda nyata jujur (Steel dan Torrie, 1991), dengan tools SPSS versi 20 untuk uji Tukey HSD. Level enzim rennet dan Lactobacillus plantarum YN 1.3 yang digunakan adalah A0: Enzim Rennet 10\% + Lactobacillus plantarum YN 1.3 0\%, A1: Enzim Rennet $8 \%+$ Lactobacillus plantarum YN 1.3 2\%, A2: Enzim Rennet $6 \%+$ Lactobacillus plantarum YN $1.34 \%$, A3: Enzim Rennet 4\% + Lactobacillus plantarum YN $1.36 \%$ dan A4: Enzim Rennet $2 \%+$ Lactotobacillus plantarum YN $1.38 \%$.

Variabel yang diamati pada penelitian ini adalah: $\mathrm{pH}$, Curd dan Total Padatan.

\section{Pengukuran variabel penelitian.}

pH keju (Walstra et al., 1999).

Sebelum $\mathrm{pH}$ meter digunakan, angka $\mathrm{pH}$ distabilkan terlebih dahulu sampai menunjukkan angka 7. Ambil $50 \mathrm{ml}$ sampel dan masukkan kedalam Erlenmeyer kemudian elektroda alat dicelupkan kedalam sampel setelah skala konstan baca angka yang tertera pada skala meternya.

Curd Keju (Coggins, 1991). Total curd merupakan parameter untuk mengetahui banyaknya curd yang terbentuk setelah kasein susu digumpalkan dan telah dipisah dengan whey. Total curd yang tinggi dan whey yang rendah menunjukkan banyaknya curd yang terbentuk. Total curd dapat dihitung dengan menggunakan rumus sebagai berikut :

Total Curd $(\%)=\frac{\text { berat curd }}{\text { volume susu awal }} \times 100$

Total Padatan Keju (Sumarmono dan Suhartati, 2010). Pengukuran total padatan dilakukan dengan menggunakan metode pengeringan yaitu sebagai berikut : Cawan dipanaskan dalam oven dengan suhu $105^{\circ} \mathrm{C}$ selama 1 jam, didinginkan dalam desikator selama 1-2 jam lalu timbang (A), kemudian masukkan sampel sebanyak 5 gram lalu ditimbang (B). Selanjutnya sampel dimasukkan kedalam oven dengan suhu $100^{\circ} \mathrm{C}$ selama 24 jam sampai diperoleh berat konstan (C). Dengan perhitungan sebagai berikut: 
Total padatan $(\%)=\frac{C-A}{B-A} \times 100$

\section{HASIL DAN PEMBAHASAN}

Hasil rataan variabel $\mathrm{pH}$, curd dan total padatan keju dengan perlakuan enzim rennet dan Lactobacillus plantarum YN 1.3 tercatum pada Tabel 1 dibawah ini.

\section{pH Keju}

Data rataan analisis $\mathrm{pH}$ pada Tabel 1 menunjukkan bahwa rataan nilai $\mathrm{pH}$ menggunakan perlakuan enzim rennet dan Lactobacillus plantarum YN 1.3 yang berbeda menghasilkan nilai $\mathrm{pH}$ keju yang beragam antara 5,5 - 5,3. Nilai $\mathrm{pH}$ keju dengan perlakuan A4 (enzim rennet 2\% dan Lactobacillus plantarum YN $1.3 \quad 8 \%$ ) menghasilkan nilai $\mathrm{pH}$ keju terendah yakni 5,3, sedangkan perlakuan A0 (enzim rennet 10\% dan Lactobacillus plantarum YN 1.3 0\%) menghasilkan nilai $\mathrm{pH}$ keju yang tinggi yakni 5,5.

Berdasarkan hasil analisis sidik ragam menunjukkan bahwa perlakuan enzim rennet dan Lactobacillus plantarum YN 1.3 memberikan pengaruh berbeda tidak nyata $(\mathrm{P}>0,05)$ terhadap nilai $\mathrm{pH}$ yang dihasilkan.

Nilai pH keju yang dihasilkan dengan penambahan Lactobacillus plantarum $Y N$ 1.3 menghasilkan $\mathrm{pH}$ yang lebih rendah. Banyaknya penambahan kultur BAL, maka nilai $\mathrm{pH}$ semakin rendah, hal ini disebabkan oleh pengaruh kosentrasi BAL yang akan merombak laktosa dalam susu menjadi asam laktat. Penurunan kadar $\mathrm{pH}$ keju dipengaruhi oleh jumlah asam laktat yang dihasilkan oleh mikroorganisme, dimana semakin tinggi asam laktat maka nilai $\mathrm{pH}-$ nya semakin rendah. Turunnya nilai $\mathrm{pH}$ keju karena adanya aktivitas bakteri asam laktat dalam keju tersebut (De Souza et al., 2003). Hal tersebut berkaitan dengan semakin meningkatnya jumlah bakteri asam laktat yang menggunakan laktosa. Semakin banyak sumber gula yang dapat dimetabolisir maka semakin banyak pula asam-asam organik yang dihasilkan

Tabel 1. Rataan Pengaruh Perlakuan Terhadap pH, Curd dan Total Padatan

\begin{tabular}{llllll}
\hline Variabel & $\mathrm{A} 0$ & $\mathrm{~A} 1$ & $\mathrm{~A} 2$ & $\mathrm{~A} 3$ & $\mathrm{~A} 4$ \\
\hline $\mathrm{pH}$ & 5,5 & 5,4 & 5,4 & 5,3 & 5,3 \\
Curd $(\%)$ & $49,05^{\mathrm{a}}$ & $58,73^{\mathrm{b}}$ & $65,42^{\mathrm{c}}$ & $71,50^{\mathrm{d}}$ & $72,75^{\mathrm{d}}$ \\
Padatan $(\%)$ & $69,04^{\mathrm{a}}$ & $70,82^{\mathrm{b}}$ & $71,82^{\mathrm{bc}}$ & $72,73^{\mathrm{c}}$ & $74,41^{\mathrm{d}}$ \\
\hline
\end{tabular}

Ket : Superskrip yang berbeda pada baris yang sama artinya berbeda sangat nyata $(\mathrm{P}<0,01)$ 
sehingga secara otomatis $\mathrm{pH}$ juga akan semakin rendah (Desai et al., 1994). Rataan $\mathrm{pH}$ keju yang dihasilkan pada penelitian ini berkisar antara 5,5-5,3. Menurut Walstra et al. (1999) pH keju berkisar antara 5,1 5,6 .

\section{Curd Keju}

Data rataan analisis curd pada Tabel 1 menunjukkan bahwa perlakuan enzim rennet dan Lactobacillus plantarum YN 1.3 yang berbeda menunjukkan hasil yang beragam berkisar antara 49,05\% - 72,75\%. Curd keju tertinggi diperoleh pada perlakuan A4 (enzim rennet $2 \%$ dan Lactobacillus plantarum YN 1.3 8\%), sedangkan curd terendah dihasilkan dari perlakuan A0 (enzim rennet $10 \%$ dan Lactobacillus plantarum YN $1.30 \%$ ).

Berdasarkan hasil analisis sidik ragam menunjukkan bahwa perlakuan A0 (enzim rennet $10 \%$ dan Lactobacillus plantarum YN $1.30 \%$ ), A1 (enzim rennet 8\% dan Lactobacillus plantarum YN 1.3 2\%), A2 (enzim rennet $6 \%$ dan Lactobacillus plantarum YN 1.3 4\%), A3 (enzim rennet $4 \%$ dan Lactobacillus plantarum YN $1.36 \%$ ) dan A4 (enzim rennet $2 \%$ dan Lactobacillus plantarum $Y N$ $1.38 \%$ ) memberikan pengaruh yang berbeda sangat nyata $(\mathrm{P}<0,01)$ terhadap curd keju yang dihasilkan.

Hasil uji lanjut Beda Nyata Jujur menunjukan bahwa curd keju pada perlakuan A0 (enzim rennet $10 \%$ dan
Lactobacillus plantarum YN $1.3 \quad 0 \%)$ berbeda nyata lebih rendah dengan perlakuan A1 (enzim rennet $8 \%$ dan Lactobacillus plantarum YN $1.32 \%$ ), A2 (enzim rennet $6 \%$ dan Lactobacillus plantarum YN 1.3 4\%), A3 (enzim rennet 4\% dan Lactobacillus plantarum YN 1.3 $6 \%$ dan A4 (enzim rennet $2 \%$ dan Lactobacillus plantarum YN $1.3 \quad 8 \%$ ). Selanjutnya perlakuan A1 (enzim rennet 8\% dan Lactobacillus plantarum YN 1.3 $2 \%$ ) berbeda nyata dari perlakuan A2 (enzim rennet $6 \%$ dan Lactobacillus plantarum YN $1.34 \%$ ), A3 (enzim rennet 4\% dan Lactobacillus plantarum YN 1.3 $6 \%$ ), dan A4 (enzim rennet 2\% dan Lactobacillus plantarum YN $1.3 \quad 8 \%$ ). Kemudian perlakuan A2 (enzim rennet 6\% dan Lactobacillus plantarum YN 1.3 4\%) berbeda nyata dari perlakuan A3 (enzim rennet $4 \%$ dan Lactobacillus plantarum $Y N$ $1.36 \%$ ), dan A4 (enzim rennet 2\% dan Lactobacillus plantarum YN $1.3 \quad 8 \%$ ). Selanjutnya perlakuan A3 (enzim rennet 4\% dan Lactobacillus plantarum YN 1.3 $6 \%$ ) tidak berbeda nyata dengan perlakuan A4 (enzim rennet 2\% dan Lactobacillus plantarum YN $1.38 \%$ ).

Dari data tersebut dapat dijelaskan bahwa curd dipengaruhi oleh Lactobacillus plantarum YN 1.3 yang digunakan. Meningkatnya jumlah BAL juga mempengaruhi curd yang dihasilka. Fox et al. (2000) menyatakan bahwa aktivitas 
protease selama koagulasi dipengaruhi oleh keasaman susu dan mempengaruhi kekuatan curd.

Curd ditekan agar diperoleh bentuk keju yang dikehendaki sekaligus merupakan proses pengurangan air. Berg (1988) menambahkan penekanan keju bertujuan untuk memberikan bentuk pada keju, memisahkan whey dari curd, menjadikan curd lebih padat dan agar keju memiliki struktur yang homogen. Kondisi yang sangat asam ini menyebabkan curd yang terbentuk akan menjadi lebih banyak. Rataan curd keju yang dihasilkan pada penelitian ini berkisar antara 49,05\% 72,75\%. Menurut Nugroho (2012) rataan curd keju yang dihasilkan berkisar antara $49,282-79,4019$.

\section{Total Padatan Keju}

Data rataan analisis total padatan keju seperti tercantum pada Tabel 1 menunjukkan bahwa rataan total padatan yang diperoleh pada keju dengan perlakuan enzim rennet dan Lactobacillus plantarum YN 1.3 yang berbeda menunjukan hasil yang beragam berkisar antara 69,04\% $74,41 \%$. Nilai rataan total padatan pada keju tertinggi diperoleh pada perlakuan A4 (enzim rennet $2 \%$ dan Lactobacillus plantarum YN $1.38 \%$ ), sedangkan total padatan terendah di hasilkan dari perlakuan A0 (enzim rennet $10 \%$ dan Lactobacillus plantarum YN $1.30 \%$ ).
Berdasarkan hasil analisis sidik ragam menunjukkan bahwa perlakuan A0 (enzim rennet $10 \%$ dan Lactobacillus plantarum YN 1.3 0\%), A1 (enzim rennet 8\% dan Lactobacillus plantarum YN 1.3 2\%), A2 (enzim rennet $6 \%$ dan Lactobacillus plantarum YN 1.3 4\%), A3 (enzim rennet $4 \%$ dan Lactobacillus plantarum YN 1.3 6\%), dan A4 (enzim rennet $2 \%$ dan Lactobacillus plantarum YN $1.38 \%$ ) memberikan pengaruh yang berbeda sangat nyata $(\mathrm{P}<0,01)$ terhadap total padatan keju yang dihasilkan.

Hasil uji lanjut beda nyata jujur menunjukan bahwa total padatan keju pada perlakuan A0 (enzim rennet $10 \%$ dan Lactobacillus plantarum YN $1.3 \quad 0 \%)$ berbeda nyata lebih rendah dengan perlakuan A1 (enzim rennet $8 \%$ dan Lactobacillus plantarum YN $1.32 \%$ ), A2 (enzim rennet $6 \%$ dan Lactobacillus plantarum YN $1.34 \%$ ) A3 (enzim rennet 4\% dan Lactobacillus plantarum YN 1.3 $6 \%$ ) dan A4 (enzim rennet 2\% dan Lactobacillus plantarum YN $1.3 \quad 8 \%$ ). Selanjutnya perlakuan A1 (enzim rennet 8\% dan Lactobacillus plantarum YN 1.3 $2 \%$ ) tidak berbeda nyata dengan perlakuan A2 (enzim rennet $6 \%$ dan Lactobacillus plantarum YN $1.34 \%$ ) tapi berbeda nyata dengan perlakuan A3 (enzim rennet $4 \%$ dan Lactobacillus plantarum YN 1.3 6\%), A4 (enzim rennet $2 \%$ dan Lactobacillus plantarum YN 1.3 6\%). Kemudian 
perlakuan A2 (enzim rennet $6 \%$ dan Lactobacillus plantarum YN 1.3 4\%) tidak berbeda nyata dengan perlakuan A3 (enzim rennet $4 \%$ dan Lactobacillus plantarum $Y N$ $1.36 \%$ ) tapi berbeda nyata dengan perlakuan A4 (enzim rennet $2 \%$ dan Lactobacillus plantarum YN 1.3 8\%). Selanjutnya perlakuan A4 (enzim rennet 2\% dan Lactobacillus plantarum YN 1.3 $8 \%$ ) berbeda nyata lebih tinggi dengan perlakuan A3 (enzim rennet $4 \%$ dan Lactobacillus plantarum YN 1.3 6\%), A2 (enzim rennet $6 \%$ dan Lactobacillus plantarum YN $1.34 \%$ ), dan A1 (enzim rennet $8 \%$ dan Lactobacillus plantarum YN $1.32 \%)$

Dari data tersebut dapat dijelaskan bahwa total padatan dipengaruhi oleh Lactobacillus plantarum YN 1.3 yang digunakan. Meningkatnya jumlah BAL juga mempengaruhi total padatan yang dihasilkan. Semakin tinggi tingkat keasaman susu yang dihasilkan oleh bakteri asam laktat menyebabkan kemampuan mengikat air semakin tinggi pada saat koagulasi. Menurut Joshi (2004) menyatakan bahwa pada koagulasi dengan asam, semakin rendah $\mathrm{pH}$ penggumpalan maka kemampuan curd untuk menahan air semakin besar sehingga jumlah kadar air yang dihasilkan semakin besar, hal ini disebabkan karena proses pengasaman dapat bekerja secara optimum dalam membantu kerja enzim rennet untuk mempercepat proses koagulasi, dan mampu menghasilkan curd yang kompak serta memiliki rendemen yang tinggi.

Koagulasi pada kondisi asam yang optimum untuk aktivitas enzim renin mampu menghasilkan curd yang kompak dan kokoh, sehingga pada saat curd dipotong, tidak banyak lemak dan kasein yang hilang bersama whey. lebih banyak lemak yang dapat dipertahankan dalam curd maka dapat menghasilkan rendemen keju yang lebih tinggi (Metzger et al., 2000). Rataan total padatan keju yang dihasilkan pada penelitian ini berkisar antara $69,04 \%$ - 74,41\%. Menurut Supriyanti dan Fitria (2014) total padatan keju berkisar antara 45,51-84,70.

\section{KESIMPULAN}

Berdasarkan hasil pembahasan dan analisis data dapat disimpulkan bahwa keju dengan pemanfaatan enzim rennet $2 \%$ dan Lactobacillus plantarum YN $1.3 \quad 8 \%$ menghasilkan $\mathrm{pH}$, curd dan total padatan keju terbaik.

\section{DAFTAR PUSTAKA}

Berg, J.C.T.v D. 1988. Dairy Technology In The Tropics And Substropics. PUDOC Wageningen Agricultural University.

De Souza, C.F.V., T.D. Rosa, M.A.Z. Ayub. 2003. Change in the 
microbiological

and physicochemical of Serrano chese during manufacture and ripening. Braz Journal Microbiol 34 (3): 260266.

Desai, S.R., V.A. Toro and V. Joshi. 1994. Utilization of different fruit in the manufacture of yoghurt. Indian Journal of Dairy Sci. 47 : 870-874.

Fox, P. F., T.P. Guinee, T.M. Cogan and P.L.H. McSweeney. 2000. Fundamentals of Cheese Sciense. Aspen Publishers, Inc. Maryland.

Joshi, N., K. Muthukumarappan dan R. I. Dave. 2004. Effect of calcium on mikrostrukture and meltability of part skim Mozzarella Cheese. Journal Dairy Science. 7: 19751985.

Metzger, L. E., D. M. Barbano, M. A. Rudan dan P. S. Kindstedt. 2000. Effect of milk preacidification on low fat Mozzarella Cheese: I. Composition and Yield. Journal Dairy Science. 83:648-658.

Nugroho, Puji Raharjo, 2012. Pengaruh Penggunaan Getah Biduri (calotropis gigantae) Terhadap Kualitas Fisik dan Kimia Keju Asal Susu Kambing. Skripsi Fakultas Pertanian, Universitas Sebelas Maret Surakarta.

Supriyanti, F. M. T dan P.F. Fitria, 2014. Fortifikasi lemon pada produksi keju cottage serta analisis kandungan gizinya. Prossiding Seminar Nasional Sains dan Pendidikan Sains IX, Fakultas Sains dan Matematika, UKSW. Vol 5(1) Pp: 530-535

Steel, R.G.D dan J.H. Torrie. 1991. Prinsip dan Prosedur Statistika. Gramedia Pustaka Utama, Jakarta.
Walstra, P.T.J. Geutrs., A. Noomen., A. Jellema,. M.A.J.S. Va Bokel. 1999. Dairy Technology. Principles of Milk. Properties and Processes. By Marcel Dekker, Inc New York. Basel 